\title{
Parameters structuring macrophyte communities in rivers and lakes - results from a case study in North-Central Poland
}

\author{
K. Szoszkiewicz ${ }^{(1), \star}$, H. Ciecierska ${ }^{(2)}$, A. Kolada ${ }^{(3)}$, S.C. Schneider ${ }^{(4)}$, \\ M. Szwabińska ${ }^{(1)}$, J. Ruszczyńska ${ }^{(2)}$
}

Received February 11, 2014

Revised June 18, 2014

Accepted November 6, 2014

\section{Key-words: macrophytes, lakes, rivers, plant ecology, ecological assessment}

\section{ABSTRACT}

\begin{abstract}
We analysed macrophyte species composition and abundance, water chemistry and hydromorphological parameters of all major river stretches and lakes in the catchment of the lowland river Wel, Poland. We studied (i) which hydromorphological and physico-chemical factors best explained macrophyte species composition, (ii) if environmental factors structuring macrophyte communities were different between rivers and lakes; and (iii) if macrophyte indices developed to indicate eutrophication correlated with nutrient concentrations. Based on two-way indicator species analysis, correlation analysis and canonical correspondence analysis, we found that river substrate was most important in structuring macrophyte species composition and abundance in rivers, while water quality parameters were most important in lakes; species richness and diversity were correlated with river size and substrate type in rivers, but not in lakes; the relative abundance of macrophyte growth forms was best explained by total organic carbon and Secchi depth in lakes, but it was not correlated with any of the water chemical or hydromorphological parameters in rivers. Irrespective of which factors best explained macrophyte community composition, macrophyte metrics developed to indicate ecological status responded most strongly to total phosphorus concentrations, both in rivers and lakes. We conclude that macrophyte metrics are valuable tools for ecological status assessment also in ecosystems where parameters other than nutrients shape macrophyte community composition.
\end{abstract}

\section{RÉSUMÉ}

Paramètres structurant les communautés de macrophytes dans les rivières et les lacs résultats d'une étude de cas dans le Centre-Nord de la Pologne

Mots-clés : macrophytes, lacs, rivières,
Nous avons analysé la composition spécifique et l'abondance de macrophytes, la chimie de l'eau et les paramètres hydromorphologiques de tous les principaux tronçons des rivières et les lacs du bassin versant de la rivière de plaine Wel, en Pologne. Nous avons étudié, (i) les facteurs hydromorphologiques et physicochimiques qui expliquent le mieux la composition des espèces de macrophytes,

(1) Poznań University of Life Sciences, Wojska Polskiego 28, 60-637 Poznań, Poland

(2) University of Warmia and Mazury in Olsztyn, Department of Botany and Nature Protection, Olsztyn-Kortowo, Poland

(3) Institute of Environmental Protection-National Research Institute, Warsaw, Poland

(4) Norwegian Institute for Water Research, Oslo, Norway

*Corresponding author: kszoszk@up.poznan.pl 
écologie

végétale,

évaluation

écologique (ii) si les facteurs environnementaux structurant les communautés de macrophytes étaient différents entre les rivières et les lacs, et (iii) si les indices macrophytiques développés pour indiquer l'eutrophisation sont corrélés avec les concentrations de nutriments. Basée sur l'analyse des espèces indicatrices, l'analyse de corrélation et l'analyse de correspondance canonique, nous avons trouvé que le substrat de la rivière était plus important dans la structuration de la composition des espèces de macrophytes et leur abondance dans les rivières, tandis que les paramètres de qualité de l'eau étaient les plus importants dans les lacs; la richesse en espèces et la diversité sont corrélées avec la taille de la rivière et le type de substrat dans les rivières, mais pas dans les lacs; l'abondance relative des formes de croissance de macrophytes a été mieux expliquée par le carbone organique total et la profondeur de Secchi dans les lacs, mais elle n'était corrélée avec aucun des paramètres hydromorphologiques ou chimiques de l'eau dans les rivières. Indépendamment des facteurs expliquant le mieux la composition des communautés de macrophytes, les métriques macrophytes développées pour indiquer l'état écologique ont répondu le plus fortement aux concentrations de phosphore total, à la fois dans les rivières et les lacs. Nous concluons que les métriques macrophytes sont des outils précieux pour l'évaluation de l'état écologique aussi dans les écosystèmes où des paramètres, autres que les nutriments structurent la composition des communautés de macrophytes.

\section{INTRODUCTION}

The watershed approach of the Water Framework Directive (WFD, EU 2000) requires integrated management of all water resources in a catchment. Thus, river basin management plans must include all categories of surface waters. In consequence, methods for assessing ecological status for a range of biological quality elements, as defined in Annex $V$ of the WFD, had to be established for both rivers and lakes.

Tolerances and preferences of aquatic macrophytes to environmental factors are different in standing and running waters due to the influence of flow velocity (Elster, 1962; Kelly and Whitton, 1998). A high flow velocity in rivers can, on the one hand, lead to a better supply of nutrients compared to lentic systems, resulting in a higher primary production for a given nutrient concentration than is encountered in lakes (Horne and Goldman, 1994). On the other hand, in lotic systems, the mechanical stress induced by the current may also cause reduced primary production of plants (Ohle, 1955), which might lead to narrower ecological optima of macrophyte species than is encountered in lakes.

Several studies have demonstrated the influence of hydrology and geomorphology on the distribution and abundance of aquatic plants in lotic and lentic systems (Lacoul and Freedman, 2006 and extensive literature cited therein). Many authors have emphasised the key importance of environmental factors, such as light availability, turbidity, humic substances or trophic status (Srivastava et al., 1995; Toivonen and Huttunen, 1995; Middelboe and Markager, 1997; Vestergaard and Sand-Jensen, 2000; Squires, 2002; Jeppesen et al., 2000), sediment characteristics (Barko and Smart, 1986) or physical factors, such as slope, wind or wave action (Duarte and Kalff, 1986) in determining aquatic vegetation patterns. The manifold of determinants influencing macrophyte communities in rivers and lakes raises the question of the diagnostic potential and applicability of macrophyte indices for ecological status assessment. This issue has become particularly important after the widespread implementation of biological monitoring with respect to the demands of the European Water Framework Directive. Specifically, it has been hypothesised that it is "very unlikely that macrophyte species composition could provide a reliable bioindicator of the surrounding nutrient (N,P) status" (Demars and Edwards, 2009), given that parameters other than nutrient concentrations, e.g. hydrological parameters, explained more of the observed variation in macrophyte species distribution than nutrients. 


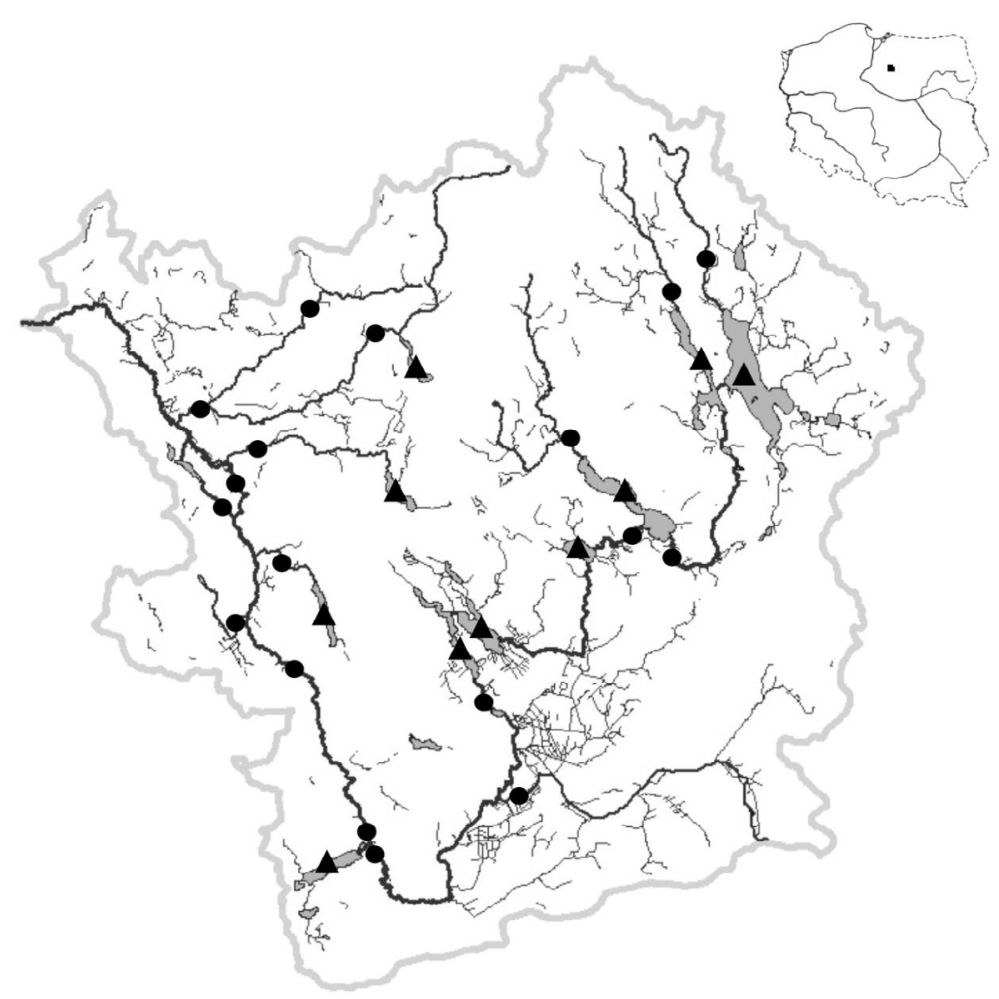

\section{Figure 1}

Location of the sampling sites in lakes (triangles, $n=10$ ) and rivers (circles, $n=18$ ) in the Wel catchment in Central Poland.

In contrast, we here show that macrophyte metrics may very well indicate nutrient concentrations, even if macrophyte communities are mainly structured by parameters other than nutrient concentrations. On this account, we analysed the macrophyte species composition and abundance, water chemistry and hydromorphological parameters in rivers and lakes located within a lowland catchment in North-Central Poland. We hypothesised that (i) even within one catchment, macrophyte communities in rivers and lakes are shaped by different habitat parameters; but that (ii) macrophyte metrics developed to detect eutrophication pressure would nonetheless correlate with water phosphorus concentrations, both in rivers and lakes.

\section{MATERIAL AND METHODS}

\section{$>$ VEGETATION DATA}

The study was undertaken in the catchment of the river Wel, located in North-Central Poland (Soszka, 2011, www.dewelopment.eu, Figure 1). The river Wel is $107.5 \mathrm{~km}$ long, and its catchment size is $822 \mathrm{~km}^{2}$. More than $70 \%$ of the catchment is subjected to agricultural use $(12 \%$ extensive and $60 \%$ intensive); natural and semi-natural areas occupy approximately $27 \%$ and urban areas about 1\% (Błachuta and Pasztaleniec, 2011). The landscape and landuse forms in the catchment are representative for Polish lowlands. Within the catchment, 15 river stretches, each with a watershed area exceeding $10 \mathrm{~km}^{2}$, and all 10 lakes which had a surface area greater than $0.5 \mathrm{~km}^{2}$, were studied (Figure 1).

Macrophyte surveys were carried out in the peak of the vegetation season 2009 (June-August) using standard Polish monitoring methodologies for rivers (Szoszkiewicz et al., 2010a) and lakes ( Ciecierska and Kolada, 2014). Eighteen representative sites were selected within the 15 river water bodies. At each river site all submerged (charids, mosses, liverworts, potamids, elodeids and large filamentous algae), floating-leaved (free-floating and rooted) and emergent 


\section{Table I}

The macrophyte metrics (mean and range) calculated for 18 river sites and 10 lakes in the Wel catchment surveyed in 2009.

\begin{tabular}{|c|c|c|c|}
\hline Macrophyte variable & Short code & Rivers & Lakes \\
\hline Species richness & $\mathrm{N}$ & $19(6-46)$ & $43(31-54)$ \\
\hline Shannon diversity & $\mathrm{H}^{\prime}$ & $0.74(0.03-1.71)$ & $2.04(1.61-2.35)$ \\
\hline Evenness & $\mathrm{J}$ & $0.24(0.01-0.50)$ & $0.45(0.30-0.70)$ \\
\hline \multicolumn{4}{|c|}{ Proportion of area occupied by species from growth forms in total area vegetated: } \\
\hline stoneworts & \%Chara & $0.1(0.0-1.0)$ & $1.4(0.0-10.9)$ \\
\hline submerged plants & \%Subm & $24.0(0.0-81.0)$ & $6.2(0.1-51.9)$ \\
\hline rooted floating-leaved plants & \%Float & $4.4(0.0-44.1)$ & $6.1(0.0-27.4)$ \\
\hline emergent plants & \%Emerg & $51.6(3.1-90.6)$ & $73.6(20.4-97.9)$ \\
\hline Macrophyte Index for Rivers & MIR & $41.1(27.0-57.0)$ & - \\
\hline Ecological State Macrophyte Index & ESMI & - & $0.371(0.199-0.636)$ \\
\hline
\end{tabular}

plants (species connected with wetlands and marsh habitats including real helophytes and semi-terrestrial plants, at least rooted in water) were examined by wading along a distance of $100 \mathrm{~m}$. The abundance of each taxon was estimated according to a nine-point scale (van der Maarel, 1979). Macrophyte taxa were determined to species level where possible, except for some large benthic algae which were determined to genus. The taxonomical identification was carried out according to Stace (1997). Aquatic vegetation of all 10 lakes with an area exceeding $0.5 \mathrm{~km}^{2}$ was surveyed along belt transects with a width of $30 \mathrm{~m}$. The number of transects in each lake ranged from 10 to 26 and was calculated from the formula elaborated by Jensen (1977), which is based on lake area and shoreline length. Within each transect all macrophyte species and plant communities of submerged, floating-leaved and emergent vegetation were recorded and their abundance was estimated according to a seven-point scale (Braun-Blanquet, 1964). A plant community was defined as a stand of distinct vegetation of a minimum size of $1 \mathrm{~m}^{2}$ and a plant cover $>25 \%$. The maximum colonisation depth and total vegetation cover were noted in each transect. Data collected on transects were averaged and recalculated into entire lake level to obtain one assessment result per lake.

For each river site and each lake, a set of macrophyte metrics was calculated, including: species richness, Shannon diversity index (Shannon and Weaver, 1949), evenness index (Pielou, 1966) and the proportion of the area occupied by the main macrophyte growth forms, i.e. charophytes, vascular submerged, floating-leaved and emergent plants (Westlake, 1975) in the total area vegetated (Table I). Moreover, two indices used in routine river and lake monitoring in Poland were calculated: the Macrophyte Index for Rivers (MIR, Szoszkiewicz et al., 2010a) and the Ecological State Macrophyte Index (ESMI, Ciecierska and Kolada, 2014) for lakes. Both metrics, MIR and ESMI, were developed to evaluate ecological status of a water body by addressing the degree of eutrophication. For each river site, MIR was calculated based on the presence and abundance of those macrophyte species that were allocated a degradation score by Szoszkiewicz et al. (2010a). MIR scores range from 10 to 100, where 10 denote degraded rivers and 100 rivers of the highest quality. For each lake, ESMI was calculated based on the spatial and syntaxonomical structure of macrophyte communities and their abundance (more methodological details in Ciecierska and Kolada, 2014). The ESMI index ranges from 0 to 1 , where 1 denotes undisturbed conditions and 0 the most degraded ones with respect to eutrophication.

\section{$>$ CHEMICAL DATA}

At each river site, water samples were collected monthly from February to November 2009. Samples were not taken in January and December due to very low temperatures and presence of an ice cover. Lake water was sampled monthly during the vegetation season, from April to October 2009. Samples were taken from the deepest point of a lake using a tube; in stratified lakes from the whole epilimnion and in polymictic lakes from the whole water depth 
(integrated sample, water sampled every $1 \mathrm{~m}$ ). In rivers, $\mathrm{pH}$, alkalinity, conductivity, nitrate, ammonium, total nitrogen, soluble reactive phosphate, total phosphorus, and total organic carbon were analysed according to Polish standard methods (more methodological details in Zbierska et al., 2011). In lakes, Secchi disc reading was included in addition (Table II). For the chemical samples the yearly maximum value of each component was used for statistical analysis.

\section{> HYDROMORPHOLOGICAL DATA}

The hydromorphological survey was performed according to the River Habitat Survey procedure (RHS, Environment Agency, 2003) for running waters and the Lake Habitat Survey procedure (LHS, Rowan et al., 2006) for standing waters. For rivers the Habitat Modification Score (HMS) and for lakes the Lake Habitat Modification Score (LHMS) were calculated. These indices express the level of hydromorphological degradation of aquatic ecosystems, mainly due to abundance of engineering facilities, reinforcements and bank resections. HMS values range between 0 and 100 and LHMS between 0 and 48. The higher the value of these indices, the more modified is the water body. Moreover, for rivers the Habitat Quality Assessment (HQA, Environment Agency, 2003) was derived, which indicates the presence and abundance of natural elements as bars, cliffs, flow type diversity, land use in the distance of $50 \mathrm{~m}$ from the bank and development of bank trees. HQA values range between 0 and 100; the higher the value, the more natural is the ecosystem.

In addition, from the RHS and LHS datasets, two other metrics proposed by Raven et al. (1998), the bank vegetation structure index (BankVeg) and the bank features index (BankFeat), were calculated (Table II). The first index reflects the complexity of the bank vegetation assessed in 4-point scale (bare, uniform, simple, complex) and ranges from 0 (bare or uniform vegetation) to 40 (simple or complex vegetation of bank and bank top). The second index reflects the diversity and naturalness of physical structure through (e.g. bars and eroding cliffs) assessed according to the score values derived for each feature by Raven et al. (1998). The substrate in both rivers and lakes, and also depth and width in rivers and depth and surface area in lakes were recorded (Table II).

\section{$>$ DATA PROCESSING}

The study sites, rivers and lakes separately, were grouped according to their macrophyte species composition based on two-way indicator species analysis (TWINSPAN, Hill, 1979) using PISCES Community Analysis Package 4. TWINSPAN was set up to include nine "cut" levels (fully utilizing nine-point species abundance scale), five as the maximum number of indicators per cut level, five as the minimum cluster size to be divided, and weighting for each taxa 'cut' level in proportion to their abundance.

Data were tested for normality using the Shapiro-Wilk test, and were square root- or Intransformed, if required (Table II). The relationships between macrophyte metrics and environmental factors were analysed based on Pearson's linear correlation using STATISTICA software (StatSoft, 2005) and canonical correspondence analysis (CCA) using CANOCO for Windows 4.5 (ter Braak and Šmilauer, 2002). To correct for multiple testing, a Bonferroni correction with the refinement of Holmes was applied (Stahel, 1995; Bärlocher, 1999).

\section{RESULTS}

\section{> MACROPHYTE COMPOSITION IN RIVERS AND LAKES}

In surface waters of the Wel catchment, a total of 128 plant taxa were recorded, of which 103 were found in rivers and 87 in lakes. Sixty-two species were found in both standing and running waters (common species), 41 exclusively in rivers and 25 exclusively in lakes. The list of taxa identified is given in Appendix 1. 


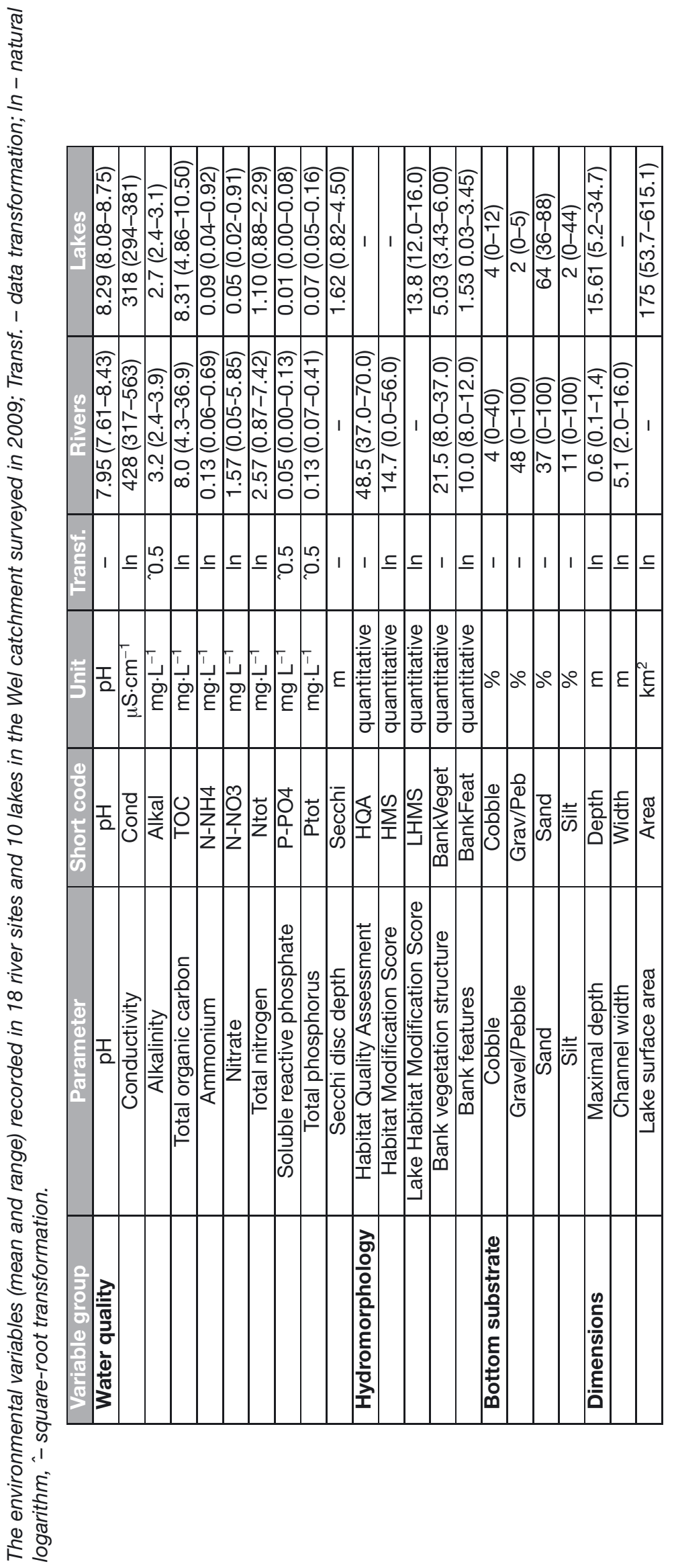


A
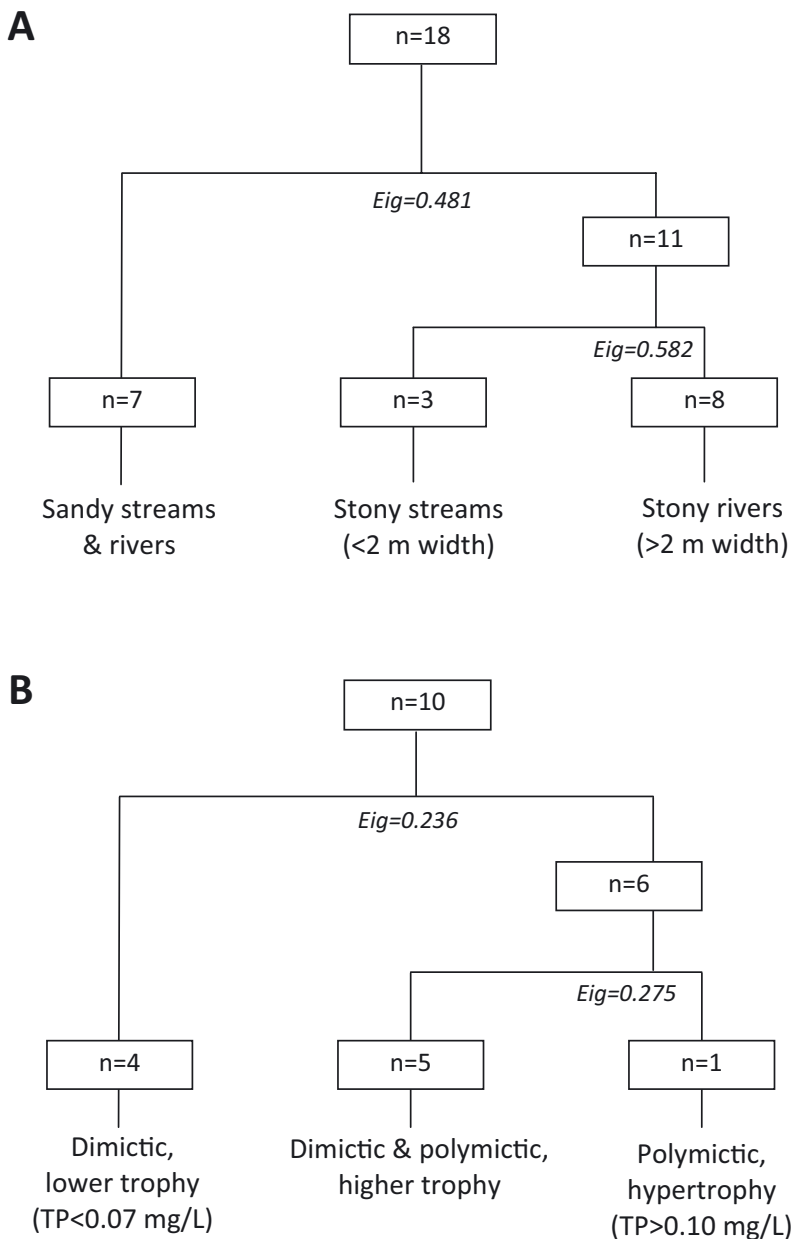

\section{Figure 2}

TWINSPAN classification of 18 river sites (A) and 10 lakes $(B)$ situated in the Wel catchment based on macrophyte composition; Eig - eigenvalues, $n$ - number of river sites/lakes, TP - annual mean concentration of total phosphorus.

The most frequent plants found exclusively in rivers were bryophytes, including mosses (Platyhypnidium riparioides, Bryum pseudotriquetrum, Sciurohypnum plumosum) and liverworts (Conocephalum conicum and Pellia endiviifolia). In addition, several algae (Hildenbrandia rivularis, Oedogonium sp., Vaucheria sp.) and emergent species (Veronica catenata, Calla palustris, Sagittaria sagittifolia, Carex paniculata) followed by two submerged plants (Potamogeton berchtoldii, P. pusillus) and free-floating species (Lemna gibba) were found exclusively in rivers, not in lakes. Among the taxa found exclusively in lakes, the group of charophytes was very distinct (Chara contraria, Lychnothamnus barbatus, Nitellopsis obtusa). Among the most common vascular plants found exclusively in lakes was a group of semi-terrestrial species: Bidens tripartita, Cardamine pratensis, Filipendula ulmaria, Senecio congestus, Scirpus tabernaemontani. As many as ten typical aquatic vascular macrophyte species were identified exclusively in lakes: Ceratophyllum submersum, Najas marina, Nymphaea alba, Polygonum amphibium, Potamogeton compressus, P. friesii, P. lucens, P. natans, Utricularia vulgaris and Vallisneria spiralis.

\section{> VEGETATION GROUPS}

TWINSPAN hierarchical classification produced three groups for rivers and three for lakes. The river classification was more distinct than the lake one, indicated by higher eigenvalues of subsequent dichotomous splits (Figure 2). TWINSPAN classification for river macrophyte 


\section{Table III}

The environmental variables significantly correlated ( $p<0.05$ after Bonferroni correction) with macrophyte metrics in 18 river sites and 10 lakes in Wel catchment; (+/-) indicates the direction of the correlations; metrics' abbreviations as in Tables I and II.

\begin{tabular}{|l|c|c|}
\hline \multirow{2}{*}{ Macrophyte variable } & \multicolumn{2}{|c|}{ Correlation with environmental variables } \\
\cline { 2 - 3 } N & $\begin{array}{c}\text { Rivers } \\
\text { (+) Width, Depth } \\
\text { (-) Ntot, Ptot, N-NO3, Cond, } \\
\text { Grav/Peb }\end{array}$ & \\
\hline H' & $(+)$ Depth, Silt & $(-)$ Cobble \\
\hline \% & $(+)$ Silt & $(+)$ Area \\
\hline \%Chara & & $\begin{array}{c}(+) \text { Secchi, BankFeat } \\
(-) \text { TOC }\end{array}$ \\
\hline \%Subm & & $(+)$ BankFeat, \\
\hline \%Float & $(+)$ Silt & $\begin{array}{c}(+) \text { TOC }(-) \text { Secchi, } \\
\text { BankFeat }\end{array}$ \\
\hline \%Emerg & & $\begin{array}{c}(+) \text { Secchi, Depth } \\
(-) \text { Ptot, Ntot }\end{array}$ \\
\hline $\begin{array}{l}\text { Ecological status indices } \\
\text { (MIR, ESMI) }\end{array}$ & (-) Ptot &
\end{tabular}

communities in the first split separated sites with fine sediment (sand and silt) from sites with stony sediment (cobble, gravel and pebble) (Figure 2A). In the second split, the group of the smallest streams (width below $2 \mathrm{~m}$ ) was separated from the larger river sections. Sandy-silty sites were characterised by the absence or very low abundance of bryophytes, and were instead dominated by emergent and free-floating plants, among which the most frequent were Equisetum fluviatile, Carex acutiformis, Myosotis palustris and Lemna minor. Stony sites were characterised by vegetation with a significant proportion of aquatic bryophytes (among the most common were Brachythecium rivulare and Fontinalis antipyretica) as well as by abundant filamentous algae (the most common was Cladophora sp.). The small streams which were separated in the second split were characterised by the presence of several semi-terrestrial species (Scirpus sylvaticus, Cardamine amara) whereas larger rivers were overgrown by typical macrophytes (Ranunculus circinatus, Berula erecta, Mentha aquatica).

TWINSPAN classification for lake macrophyte communities in the first split separated the four least eutrophic lakes from those impacted by eutrophication (Figure 2B). In the second split, the shallowest lake having the highest trophic status was separated from the other eutrophic lakes. The four least eutrophic lakes had abundant charophyte vegetation, and all were stratified during summer. All highly eutrophic lakes clustered in the first split were characterised by a lack of charophytes, generally scarce submerged vegetation and abundant rush and sedge vegetation.

\section{> PARAMETERS SHAPING VEGETATION PATTERNS IN RIVERS AND LAKES}

Different environmental factors were found to shape macrophyte vegetation in rivers and lakes (Table III). In rivers, a significant positive correlation between species richness and river width and depth, and a negative correlation with conductivity, nitrate, total nitrogen and total phosphorous were detected (Table III, Appendix 2). Total number of species in rivers was also negatively correlated with the abundance of gravel and pebble in the river bed, whereas Shannon diversity index and index of evenness $\mathrm{J}$ were positively correlated with silt in substrate. In contrast, none of the measured environmental parameters was correlated to species richness in lakes, and proportion of cobble was the only parameter correlated to Shannon diversity in standing waters (Table III). With respect to macrophyte growth forms, in rivers there was only the proportion of floating-leaved macrophytes correlated with the proportion of silt in the substrate, while in lakes different macrophyte growth forms were correlated with total organic carbon content, Secchi depth and bank features (Table III, Appendix 3). The ESMI index for lake ecological status assessment was strongly correlated with Secchi depth, total 

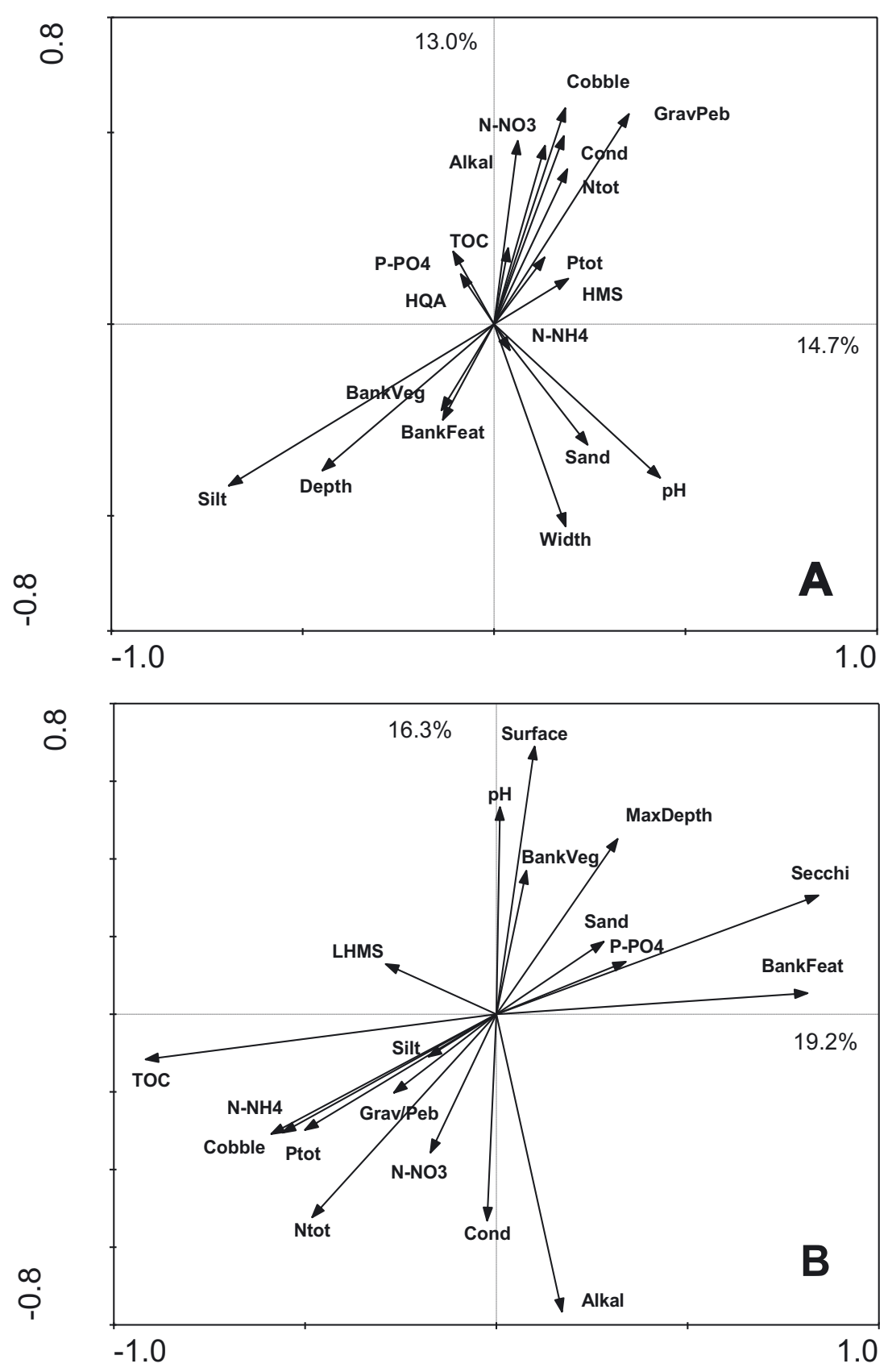

Figure 3

CCA ordination of the environmental variables structuring aquatic vegetation in river stretches $(A)$ and in lakes $(B)$ in river Wel catchment; abbreviations of the environmental parameters as in Table II.

organic carbon, total nitrogen and total phosphorus. In rivers, the MIR index was significantly correlated only with total phosphorus concentrations.

The taxonomic composition and abundance of river macrophytes were best explained by substrate (silt, gravel/pebble and cobble) (Figure 3A). This gradient was associated with river dimensions - larger rivers (deeper and wider) were associated with the silt substrate, whereas stony substrate was more abundant in smaller river sections. In contrast, the most important factors affecting aquatic vegetation in lakes were parameters related to eutrophication, such as total organic carbon, total nitrogen and Secchi depth (Figure 3B). In addition, alkalinity and surface area appeared to be important in structuring macrophyte vegetation in lakes. 


\section{DISCUSSION}

All data in our study were collected in the catchment of the lowland river Wel. Since this watershed is relatively homogeneous in terms of geographical, climatic and geological conditions (Błachuta and Pasztaleniec, 2011), a substantial part of environmental variability with respect to these parameters was reduced. This facilitates exploring the differences in the main driving factors shaping vegetation patterns between lotic and lentic ecosystems.

The vast majority of recorded taxa were common for both stagnant and running waters. Each of these two water categories, however, contained a pool of exclusive species. This set was larger in rivers than it was in lakes. While some of the differences in taxa occurrence, e.g. Potamogeton and Lemna species, between rivers and lakes, most probably are just accidental in our dataset, the occurrence of bryophytes exclusively in rivers is possibly related to their restriction to $\mathrm{CO}_{2}$ as a carbon source (Bain and Proctor, 1980) and their preference for coarse substrate. The occurrence of crust forming algae like Hildenbrandia vulgaris exclusively in rivers likely is related to their slow growth rate and preference for stony substrate and high flow velocity (Nicols, 1965; Eloranta and Kwadrans, 2004). Likewise, the absence of rootless species like Ceratophyllum submersum or Utricularia sp. from rivers is not surprising, and also the preference of charophytes and Najas marina for standing waters is known (Chambers and Prepas, 1990; Blindow, 1992; Mazej and Germ, 2008), although these species indeed also may be abundant in rivers and streams, including fast flowing parts (Schneider et al., 2000). The rare occurrence of certain species in running waters has the consequence that such species usually are not included in indicator systems developed for rivers, and the same is true vice versa for species preferably occurring in lakes. This has important consequences for bioindication and is the main reason why different indicator systems should be developed for rivers and lakes, separately. Schneider (2007) already reported that only about $60 \%$ of macrophyte indicator species used in European classification systems were common for rivers and lakes.

The relationships between macrophyte variables and environmental factors in rivers and lakes of the Wel catchment revealed on the basis of Pearson's correlation analyses were coherent with those obtained by using the multivariate technique CCA and TWINSPAN classification. All our results demonstrated that even within one river-lake system located in one catchment, the factors most strongly structuring macrophyte communities are different in rivers and lakes. While substrate was most important for macrophyte species composition and abundance in rivers, eutrophication parameters like total organic carbon, total nitrogen, total phosphorus and Secchi depth were most important in shaping macrophyte communities in lakes. This was demonstrated in spite of the relatively limited eutrophication gradient in the Wel catchment. The key role of eutrophication in determining macrophyte species composition and growth forms was reported also by other authors (e.g. Janauer et al., 2003; Clayton and Edwards, 2006). Likewise, the importance of substrate on river macrophyte community composition and abundance is in accordance with the findings by Szoszkiewicz et al. (2010b) and Schneider et al. (2012).

The proportion of different growth forms in lakes of the Wel catchment was associated primarily to total organic carbon and Secchi depth, but also to the extent of natural features of the bank structure. This relationship was reported before by Cheruvelil and Sorano (2008). They demonstrated that undisturbed bank structures were associated with a higher proportion of submerged and floating-leaved macrophytes, whereas banks adjacent to arable land and urban developments were associated with a large amount of helophytes. Moreover, the relative abundance of charophytes was associated with the size of a lake. These findings are in line with the results of our study. It should be stressed, however, that the largest lakes in our study were also less eutrophic and provided more favorable conditions for stoneworts than the smaller and more eutrophied lakes.

Unlike it was in lakes, in rivers macrophyte growth forms were not as distinctly impacted by habitat parameters. The only significant correlation was between silt substrate and the proportion of submerged plants. Conversely as it is observed in lakes, where a vertical gradient in light attenuation determines a clear vegetation zoning (Spence, 1982), in rivers the 
light availability is more homogeneous (Lacoul and Freedman, 2006) and vegetation zoning is therefore less distinct. In our study most of the analysed lakes were deep enough to demonstrate a clear light attenuation gradient, whereas rivers were generally too shallow to have a significant low-light zone. That can explain, at least partly, the lack of a relationship between macrophyte growth forms and environmental parameters in rivers in our study. Therefore, water visibility appeared an important factor for macrophyte growth in lakes but not in rivers. In running waters, the vegetation is strongly determined by water flow, a physical factor that determines plant growth forms and defines the habitats (Westlake, 1975; Dawson, 1988; Dawson and Szoszkiewicz, 1999). Only in areas with low flow is the development of vegetation typical for standing waters possible. A multitude of physical and chemical factors may control macrophyte development (Westlake, 1975; French and Chambers, 1996), like e.g. sediment composition, which in turns is influenced by the current velocity. For example, aquatic mosses may dominate in torrential and fast flowing mountain streams with abundant large boulders (Cattaneo and Fortin, 2000; Fritz et al., 2009), some phanerogams like many Potamogeton species usually grow in waters of moderate flow and sandy substrate, while others like Stuckenia pectinata or Myriophyllum spicatum are associated most frequently with clay (synthetic overview in Dawson, 1988 and Lacoul and Freedman, 2006). Also in our study mosses were associated with lotic ecosystems and almost never appeared in lakes, with the single exception of Fontinalis antipyretica, which was common in both lakes and rivers. On the other hand, the appearance of most Potamogeton species was restricted to standing waters.

Water quality, substrate and size of a river significantly affected species diversity. In rivers with a low-nutrient level, species richness was higher than in more eutrophic rivers (significant correlation between number of species and total nitrogen, total phosphorus and nitrate). Although macrophytes are regarded reliable indicators of trophic status in rivers (Carbiener et al., 1990; Robach et al., 1996; Schneider, 2007), macrophyte species richness is generally considered a poor indicator of habitat quality (Passauer et al., 2002), thus contradicting our results. This is why river macrophyte monitoring is mainly based on numerical indices considering presence and abundance of indicative plants (Schneider and Melzer, 2003; Haury et al., 2006; Fabris et al., 2009; Szoszkiewicz et al., 2010a). To confirm our results with respect to species number, the revealed relationship should be tested on a larger set of data representing a longer trophic gradient.

Our study demonstrated that the macrophyte community in lakes is mainly structured by eutrophication parameters, whereas in rivers it is controlled mainly by the type of sediment. Nevertheless, both ecological status assessment indices, MIR for rivers and ESMI for lakes, responded most strongly to water phosphorus concentrations. However, the response of ESMI was stronger than of MIR and additionally ESMI was also significantly correlated with total nitrogen, total organic carbon and Secchi depth. The stronger response to total phosphorus of the lake macrophyte index than the river one is most likely due to the higher spatial and temporal variability of water chemical parameters in rivers than in lakes (Johnson et al., 1997; Essington and Carpenter, 2000; Stendera and Johnson, 2006).

In conclusion, our results indicate that, even if macrophyte communities in aquatic ecosystems may primarily be structured by parameters other than nutrient concentrations, indices developed to indicate eutrophication may very well be applicable and give reliable assessment results.

\section{ACKNOWLEDGEMENTS}

The study was funded by the Polish-Norwegian Research Fund within the project "Development and validation of methods for integrated assessment of ecological status of rivers and lakes to support river basin management plans" (deWELopment; contract PNRF-220Al-1/07). 


\section{REFERENCES}

Bain J.T. and Proctor M.C.F., 1980. The requirement of aquatic bryophytes for free $\mathrm{CO}_{2}$ as an inorganic carbon source: Some experimental evidence. New Phytol., 86, 393-400.

Barko J.W. and Smart R.M., 1986. Sediment-related mechanisms of growth limitation in submerged macrophytes. Ecology, 67, 1328-1340.

Bärlocher F., 1999. Biostatistik. Georg Thieme Verlag, Stuttgart, Germany, p. 206.

Błachuta J. and Pasztaleniec A., 2011. Study area. In: Soszka H. (ed.), Ecological status assessment of the waters in the Wel river catchment. Guidelines for integrated assessment of ecological status of rivers and lakes to support river basin management plans. Institute of Inland Fisheries, Olsztyn [in Polish with English summary], pp. 9-34.

Blindow I., 1992. Decline of charophytes during eutrophication: comparison with angiosperms. Freshw. Biol., 28, 9-14.

Braun-Blanquet J., 1964. Pflanzensoziologie. Wien, New York, Springer.

Carbiener R., Tremolieres M., Mercier J.L. and Ortscheit A., 1990. Aquatic macrophyte communities as bioindicators of eutrophication in calcareous oligosaprobe stream waters (Upper Rhine plain, Alsace). Vegetatio, 86, 71-88.

Cattaneo A. and Fortin L., 2000. Moss distribution in streams of the Quebec Laurentian Mountains. Can. J. Botany, 78, 748-752.

Chambers P.A. and Prepas E.E., 1990. Competition and coexistence in submerged aquatic plant communities: the effect of species interactions versus abiotic factors. Freshw. Biol., 23, 541-550.

Cheruvelil K.S. and Sorano P.A., 2008. Relationships between lake macrophyte cover and landscape features. Aquat. Bot., 88, 219-227.

Ciecierska H. and Kolada A., 2014. ESMI: a macrophyte index for assessing the ecological status of lakes. Environ. Monit. Assess., 186, 5501-5517.

Clayton J. and Edwards T., 2006: Aquatic plants as environmental indicators of ecological condition in New Zealand lakes. Hydrobiologia, 570, 147-151.

Dawson H.F., 1988. Water flow and the vegetation of running waters. In: Symoens J.J. (ed.), Handbook of vegetation Sciences, Series 15: Vegetation of Inland Waters, Kluwer Academic Publishers, Dordtrecht, 283-309.

Dawson H.F. and Szoszkiewicz K., 1999. Relationships of some ecological factors with the associations of vegetation in British rivers. Hydrobiologia, 515, 117-122.

Demars B.O.L. and Edwards A.C., 2009. Distribution of aquatic macrophytes in contrasting river systems: A critique of compositional-based assessment of water quality. Sci. Tot. Env. 407, 975-990.

Duarte C.M. and Kalff J., 1986. Littoral slope as a predictor of the maximum biomass soft submerged macrophyte communities. Limnol. Oceanogr., 31, 1072-1080.

Eloranta P. and Kwadrans J., 2004. Indicator value of freshwater red algae in running waters for water quality assessment. Oceanol. Hydrobiol. St., 33, 47-54.

Elster H.J., 1962: Seetypen, Fließgewässertypen und Saprobiensystem. Internationale Revue der gesamten Hydrobiologie, 47, 211-218.

Environment Agency, 2003. River Habitat Survey in Britain and Ireland. Field Survey Guidance Manual, p. 137.

Essington T.E. and Carpenter S.R., 2000. Nutrient cycling in lakes and streams: Insights from a comparative analysis. Ecosystems, 3, 131-143.

EU, 2000. Directive 2000/60/EC of the European Parliament and of the Council of 23 October 2000 establishing a framework for Community action in the field of water policy. Official J. L 327, 2000/12/22.

Fabris M., Schneider S. and Melzer A., 2009. Macrophyte-based bioindication in rivers - A comparative evaluation of the reference index (RI) and the trophic index of macrophytes (TIM). Limnologica, 39, 40-55.

French T.D. and Chambers P.A., 1996. Habitat partitioning in riverine macrophyte communities. Freshw. Biol., 36, 509-520.

Fritz K.M., Glime J.M., Hribljan J. and Greenwood J.L., 2009. Can bryophytes be used to characterize hydrologic permanence in forested headwater streams? Ecol. Ind., 9, 681-692. 
Haury J., Peltre M.-C., Trémolières M., Barbe J., Thiébaut G., Bernez I., Daniel H., Chatenet P., HaanArchipof G., Muller S., Dutartre A., Laplace-Treyture C., Cazaubon A. and Lambert-Servien E., 2006. A new method to assess water trophy and organic pollution - the Macrophytes Biological Index for Rivers (IBMR): its application to different types of river and pollution. Hydrobiologia, 570, 153-158.

Hill M.O., 1979. TWINSPAN - a FORTRAN program for arranging multivariate data in an ordered twoway table by classification of the individuals and attributes. Cornell University, Ithaca, New York.

Horne A.J. and Goldman C.R., 1994. Limnology 2nd edn., McGraw-Hill, Inc., New York.

Janauer G.A., Hale P. and Sweeting R., 2003. Macrophyte inventory of the River Danube: A pilot study. Arch. Hydrobiol., Suppl., 147, Large Rivers 14, 9-16.

Jensen S., 1977. An objective method for sampling the macrophyte vegetation in lakes. Vegetatio, 33, 107-118.

Jeppesen E., Jensen J.P., Søndergaard M., Lauridsen T. and Landkildehus F., 2000. Trophic structure, species richness and biodiversity in Danish lakes. Changes along a phosphorus gradient. Freshw. Biol., 45, 201-218.

Johnson L.B., Richards C., Host G. and Arthur J.W., 1997. Landscape influence on water chemistry in Midwestern stream ecosystems. Freshw. Biol., 37, 193-208.

Kelly M.G. and Whitton B.A., 1998. Biological monitoring of eutrophication in rivers. Hydrobiologia, 384 , 55-67.

Lacoul P. and Freedman B., 2006. Environmental influences on aquatic plants in freshwater ecosystems. Environ. Rev., 14, 89-136.

Mazej Z. and Germ M., 2008. Competitive advantages of Najas marina L. in a process of litoral colonization in the lake Velenjsko jezero (Slovenija). Acta Biol. Slov., 51, 13-20.

Middelboe A.L. and Markager S., 1997. Depth limits and minimum light requirements of freshwater macrophytes. Freshw. Biol., 37, 553-568.

Nicols H.W., 1965. Culture and development of Hidenbrandia rivularis from Denmark and North America. Am. J. .Bot., 52, 9-15.

Ohle W., 1955. Beiträge zur Produktionsbiologie der Gewässer. Archiv für Hydrobiologie, Supplement 23, 456-479.

Passauer B., Meilinger P., Melzer A. and Schneider S., 2002. Does the structural quality of running waters affect the occurrence of macrophytes? Acta Hydroch. Hydrob., 30, 197-206.

Pielou E.C., 1966. The measurement of diversity in different types of biological collections. J. Theor. Biol., 13, 131-144.

Raven P.J., Holmes N.T.H., Dawson F.H., Fox P.J.A., Everard M., Fozzard I.R. and Rouen K.J. 1998. River Habitat Quality: the physical character of rivers and streams in the UK and Isle of Man. Environment Agency, Bristol.

Robach F., Thiebaut G., Tremolieres M. and Muller S., 1996. A reference system for continental running waters: plant communities as bioindicators of increasing eutrophication in alkaline and acidic waters in north-east France. Hydrobiologia, 340, 67-76.

Rowan J.S., Carwardine J., Duck R.W., Black A.R., Cutler M.E.J., Soutar I. and Boon P.J., 2006. Development of a technique for Lake Habitat Survey (LHS) with applications for the European Union Water Framework Directive. Aquat. Conserv., 16, 627-657.

Schneider S. and Melzer A., 2003. The Trophic Index of Macrophytes (TIM) - a new tool for indicating the trophic state of running waters. Int. Rev. Hydrobiol., 88, 49-67.

Schneider S., Krumpholz T. and Melzer A., 2000. Trophieindikation in Fließgewässern mit Hilfe des TIM (Trophie-Index Makrophyten) - Erprobung eines neu entwickelten Index im Inninger Bach (Assessment of river trophic status - implementation of the trophic index of macrophytes (TIM) in the Inninger Bach river). Acta Hydroch. Hydrob. 28, 241-249.

Schneider S.C., 2007. Macrophyte trophic indicator values from a European perspective. Limnologica, 37, 281-289.

Schneider S.C., Ławniczak A.E., Piciñska-Faltynowicz J. and Szoszkiewicz K., 2012. Do macrophytes, diatoms and non-diatom benthic algae give redundant information? Results from a case study in Poland. Limnologica, 42, 204-211.

Shannon C.E. and Weaver W., 1949. The Mathematical Theory of Communication. University of Illinois Press, Urbana. 
Soszka H. (ed.), 2011. Ecological status assessment of the waters in the Wel River catchment. Guidelines for integrated assessment of ecological status of rivers and lakes to support river basin management plans. Institute of Inland Fisheries, Olsztyn [in Polish with English summary], 320.

Spence D.H.N. 1982. The zonation of plants in freshwater lakes. Adv. Ecol. Res., 12, 37-125.

Squires M.M., Lesack L.F.W. and Huebert D., 2002. The influence of water transparency on the distribution and abundance of macrophytes among lakes of the Mackenzie Delta, Western Canadian Arctic. Freshw. Biol., 47, 2123-2135.

Srivastava D.S., Staicer C.A. and Freedman B., 1995. Aquatic vegetation of Nova Scotian lakes differing in acidity and trophic status. Aquat. Bot., 51, 181-196.

Stace C., 1997. New Flora of the British Isles. Cambridge University Press, Cambridge.

Stahel W.A., 1995. Statistische Datenanalyse - Eine Einführung für Naturwissenschaftler. Braunschweig, Vieweg Verlag, Wiesbaden.

StatSoft, Inc., 2005. STATISTICA (data analysis software system), version 7.1. www.statsoft.com.

Stendera S. and Johnson R.K., 2006. Multiscale drivers of water chemistry of boreal lakes and streams. Environ. Management, 38, 760-770.

Szoszkiewicz K., Zbierska J., Jusik Sz. and Zgoła T., 2010a. Macrophyte Method for River Assessment - manual for the assessment and classification of ecological status of running waters based on water plants. Bogucki Wydawnictwo Naukowe, Poznań [in Polish], 81.

Szoszkiewicz K., Jusik Sz., Ławniczak A.E. and Zgoła T., 2010b. Macrophyte development in unimpacted lowland rivers in Poland. Hydrobiologia, 656, 117-131.

ter Braak C.J.F. and Šmilauer P., 2002. CANOCO Reference manual and CanoDraw for Windows User's Guide: Software for Canonical Community Ordination (version 4.5). Microcomputer Power, Ithaca, USA.

Toivonen H. and Huttunen P., 1995. Aquatic macrophytes and ecological gradients in 57 small lakes in southern Finland. Aquat. Bot., 51, 197-221.

van der Maarel E., 1979. Transformation of cover-abundance values in phytosociology and its effects on community similarity. Vegetatio, 39, 97-114.

Vestergaard O. and Sand-Jensen K., 2000. Alkalinity and trophic state regulate aquatic plant distribution in Danish lakes. Aquat. Bot., 67, 85-107.

Westlake D.F., 1975. Macrophytes. In: Whitton B.A. (ed.), River ecology. Berkeley, University of California Press, California, 106-128.

Zbierska J., Ławniczak A.E., Jusik Sz., 2011. Supporting physico-chemical elements. In: Soszka H. (ed.), Ecological status assessment of the waters in the Wel river catchment. Guidelines for integrated assessment of ecological status of rivers and lakes to support river basin management plans, Institute of Inland Fisheries, Olsztyn [in Polish with English summary], 115-124. 
Appendix 1. List of plant species identified in 18 river sites and 10 lakes in Wel catchment in 2009.

Plant species common for rivers and lakes $(n=62)$

Acorus calamus L., Agrostis stolonifera L., Alisma plantago-aquatica L., Alnus glutinosa Gaertn., Berula erecta Huds., Bidens cernua L., Butomus umbellatus L., Carex acutiformis L., C. pseudocyperus L., C. riparia Curtis, C. rostrata Stokes, Ceratophyllum demersum L., Chara rudis (= Ch. globularis) (A. Braun) Leonhardi, Cicuta virosa L., Elodea canadensis Michx., Epilobium hirsutum L., Equisetum fluviatile L., E. palustre L., Eupatorium cannabinum L., Fontinalis antipyretica L., Galium palustre L., Glyceria fluitans (L.) R. Br., G. maxima (Hartm.) Holmb., Hydrocharis morsus-ranae L., Impatiens parviflora DC., Iris pseudacorus L., Lemna minor L., L. trisulca L., Lycopus europaeus L., Lysimachia thyrsiflora L., L. vulgaris L., Lythrum salicaria L., Mentha aquatica L., Myosotis palustris Hill, Myriophyllum spicatum L., Nuphar lutea (L.) Sm., Phalaris arundinacea L., Phragmites australis (Cav.)Trin. ex Steud, Poa palustris L., Polygonum persicaria L., Potamogeton alpinus Balb., P. crispus L., P. perfoliatus L., P. praelongus Wulfen, Ranunculus circinatus (=Batrachium circinatum) Sibth., R. sceleratus L., Rorippa amphibia (L.) Besser, Rumex hydrolapathum Huds., Scirpus sylvaticus L., Scrophularia umbrosa Dumort., Scutellaria galericulata L., Sium latifolium L., Solanum dulcamara L., Sparganium emersum Rehmann, S. erectum L. em. Rchb. s. S., Spirodela polyrhiza (L.) Schleid.,Stuckenia pectinata (L.) Börner (= Potamogeton pectinatus L.), Thelypteris palustris Schott, Typha angustifolia L., T. latifolia L., Veronica anagallis-aquatica L., V. beccabunga L.

Plant species identified only in rivers $(n=41)$

Batrachium trichophyllum (Chaix). Bosch, Bidens frondosa L., Brachythecium rivulare B., S. \& G., Bryum pseudotriquetrum Hedw., Calla palustris L., Callitriche cophocarpa Sendtn., Caltha palustris L., Cardamine amara L., Carex elata All., C. gracilis Curtis, C. paniculata L., Cirsium oleraceum (L.) Scop., C. palustre (L.) Scop., Cladophora sp. Kützing, Conocephalum conicum (L.) Corda., Cratoneuron filicinum Spruce, Epilobium palustre L., E. parviflorum Schreb., E. roseum Schreb., Galium uliginosum L., Hildenbrandia rivularis (Liebmann) J.Agardh, Juncus bufonius L., Lemna gibba L., Leptodictyum riparium (Hedw.) Warnst., Myosoton aquaticum (L.) Moench, Oedogonium sp., Pellia endiviifolia (Dicks.) Dum., Petasites hybridus (L.) Gaertn., B. Mey. \& Scherb., Phormidium sp., Plagiomnium undulatum (Hedw.) T.J. Kop., Platyhypnidium riparioides Hedw., Polygonum hydropiper L., Potamogeton berchtoldii Fieber, P. pusillus L., Rhizomnium punctatum (Hedw.) T. Kop., Rumex maritimus L., Sagittaria sagittifolia L., Sciuro-hypnum plumosum (Hedw.) Ignatov \& Huttunen, Stachys palustris L., Vaucheria sp. de Candolle, Veronica catenata Pennell

Plant species identified only in lakes $(n=25)$

Bidens tripartita L., Chara contraria A. Braun ex Kütz., Cardamine pratensis L., Ceratophyllum submersum L., Eleocharis palustris (L.), Filipendula ulmaria (L.) Maxim., Juncus bulbosus L., Lychnothamnus barbatus (Meyen) Leonhardi, Najas marina L., Nitellopsis obtusa (N.A.Desvaux) J.Groves, Nymphaea alba L., Peucedanum palustre (L.) Moench, Polygonum amphibium L., Potamogeton compressus L., P. friesii Rupr., P. lucens L., P. natans L, Ranunculus lingua L., Salix cinerea L., Scirpus lacustris L., S. tabernaemontani Palla, Senecio congestus (R. Brown) de Candolle, Stratiotes aloides L., Utricularia vulgaris L., Vallisneria spiralis L. 
Appendix 2. The statistically significant correlations ( $p<0.05$; after Bonferroni correction) between macrophyte metrics and environmental variables in rivers of the Wel catchment surveyed in 2009; values of $r$ Pearson correlation coefficients; variables correlated with at least one macrophyte metric marked in bold; metrics abbreviations as in Tables I and II.

\begin{tabular}{|c|c|c|c|c|c|c|c|c|}
\hline \multirow{2}{*}{$\begin{array}{l}\text { Environmental } \\
\text { variable }\end{array}$} & \multicolumn{8}{|c|}{ Macrophyte metrics } \\
\hline & $\bar{N}$ & $\mathrm{H}^{3}$ & $\mathrm{~J}$ & \%Chara & \%Subm & $\%$ Float & $\%$ Emerg & $\overline{M I R}$ \\
\hline \multicolumn{9}{|l|}{$\mathrm{pH}$} \\
\hline \multicolumn{9}{|l|}{ TOC } \\
\hline \multicolumn{9}{|l|}{ Alkal } \\
\hline Conduc & -0.62 & & & & & & & \\
\hline \multicolumn{9}{|l|}{$\mathrm{N}-\mathrm{NH} 4$} \\
\hline N-NO3 & -0.67 & & & & & & & \\
\hline Ntot & -0.64 & & & & & & & \\
\hline \multicolumn{9}{|l|}{$\mathrm{P}-\mathrm{PO} 4$} \\
\hline Ptot & -0.76 & & & & & & & -0.59 \\
\hline \multicolumn{9}{|l|}{$\mathrm{HQA}$} \\
\hline \multicolumn{9}{|l|}{ HMS } \\
\hline \multicolumn{9}{|l|}{ BankVeg } \\
\hline \multicolumn{9}{|l|}{ BankFeat } \\
\hline \multicolumn{9}{|l|}{ Cobble } \\
\hline Grav/Peb & -0.57 & & & & & & & \\
\hline \multicolumn{9}{|l|}{ Sand } \\
\hline Silt & & 0.54 & 0.52 & & & 0.98 & & \\
\hline Depth & 0.58 & 0.48 & & & & & & \\
\hline Width & 0.60 & & & & & & & \\
\hline
\end{tabular}

Appendix 3. The statistically significant correlations ( $p<0.05$; after Bonferroni correction) between macrophyte metrics and environmental variables in lakes of the Wel catchment surveyed in 2009; values of $r$ Pearson correlation coefficients; variables correlated with at least one macrophyte metric marked in bold; metrics abbreviations as in Tables I and II.

\begin{tabular}{|c|c|c|c|c|c|c|c|c|}
\hline \multirow{2}{*}{$\begin{array}{l}\text { Environmental } \\
\text { variable }\end{array}$} & \multicolumn{8}{|c|}{ Macrophyte metrics } \\
\hline & $\mathbf{N}$ & $\mathrm{H}^{3}$ & $\mathrm{~J}$ & $\%$ Chara & $\%$ Subm & \%Float & \%Emerg & ESMI \\
\hline \multicolumn{9}{|l|}{$\mathrm{pH}$} \\
\hline TOC & & & & & -0.93 & & 0.98 & \\
\hline \multicolumn{9}{|l|}{ Alkal } \\
\hline \multicolumn{9}{|l|}{ Cond } \\
\hline \multicolumn{9}{|l|}{$\mathrm{N}-\mathrm{NH} 4$} \\
\hline \multicolumn{9}{|l|}{$\mathrm{N}-\mathrm{NO} 3$} \\
\hline Ntot & & & & & & & & -0.70 \\
\hline \multicolumn{9}{|l|}{ P-PO4 } \\
\hline Ptot & & & & & & & & -0.82 \\
\hline Secchi & & & & & 0.90 & & -0.87 & 0.78 \\
\hline \multicolumn{9}{|l|}{ LHMS } \\
\hline \multicolumn{9}{|l|}{ BankVeg } \\
\hline BankFeat & & & & & 0.72 & 0.71 & -0.77 & \\
\hline Cobble & & -0.75 & & & & & & \\
\hline \multicolumn{9}{|l|}{ Grav/Peb } \\
\hline \multicolumn{9}{|l|}{ Sand } \\
\hline \multicolumn{9}{|l|}{ Silt } \\
\hline Depth & & & & & & & & 0.71 \\
\hline Area & & & & 0.79 & & & & \\
\hline
\end{tabular}

